\title{
THE INFLUENCE OF LASER RADIATION ON VEGF EXPRESSION IN THYROID TISSUE IN EXPERIMENTAL HYPOTHYROIDISM
}

\author{
E.S. Golovneva ${ }^{1}$, I.V. Smelova ${ }^{2}$ \\ ${ }^{1}$ South Ural State Medical University, Chelyabinsk, Russia; \\ ${ }^{2}$ Multidisciplinary Center for Laser Medicine, Chelyabinsk, Russia

\section{ВЛИЯНИЕ ЛАЗЕРНОГО ОБЛУЧЕНИЯ НА ЭКСПРЕССИЮ ФАКТОРА РОСТА СОСУДИСТОГО ЭНДОТЕЛИЯ В ТКАНИ ЩИТОВИДНОЙ ЖЕЛЕЗЫ НА ФОНЕ ЭКСПЕРИМЕНТАЛЬНОГО ГИПОТИРЕОЗА}

\author{
Е.С. Головнева ${ }^{1}$, И.В. Смелова ${ }^{2}$ \\ ${ }^{1}$ ФГБОУ ВО «Южно-Уральский государственный медицинский университет» Минздрава России, Челябинск; \\ ${ }^{2}$ ГБУЗ «Многопрофильный центр лазерной медицины», Челябинск
}

The aim was to study the effect of infrared laser irradiation of average intensity with the total dose of $112 \mathrm{~J} / \mathrm{cm}^{2}$ and $450 \mathrm{~J} / \mathrm{cm}^{2}$ on the expression of vascular endothelial growth factor (VEGF) in thyroid tissue in normal and hypothyroidism. The experiment was conducted on 30 male laboratory rats. Animals were removed from the experiment one day after irradiation. Expression of vascular endothelial growth factor was determined by immunohistochemical method. It was shown that laser exposure in the studied doses increases the expression of VEGF in the thyroid gland of intact animals and, to a greater extent, in hypothyroid animal groups. When comparing the effects of the two studied modes of laser exposure, it was found that VEGF expression is greater after exposition to the total dose density of $450 \mathrm{~J} / \mathrm{cm}^{2}$ on the skin surface. The obtained results could be used for further development of laser therapy methods for hypothyroidism in experiment.

Keywords: VEGF; laser radiation; thyroid gland; hypothyroidism.

Целью исследования являлось изучение воздействия инфракрасного лазерного облучения в до-

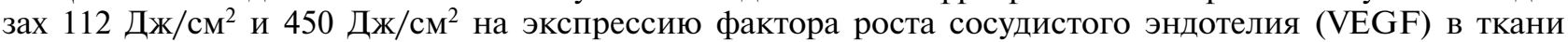
щитовидной железы в норме и при гипотиреозе. Эксперимент проведен на 30 лабораторных крысах самцах. Животные выводились из эксперимента через сутки после облучения. Экспрессия фактора роста сосудистого эндотелия определялась иммуногистохимическим методом. Показано, что лазерное воздействие в изучаемых дозах способствует повышению экспрессии VEGF в щитовидной железе интактных животных и, в большей степени, животных с моделью гипотиреоза. При сравнении эффектов двух изучаемых режимов лазерного воздействия выявлено, что экспрессия VEGF выше при

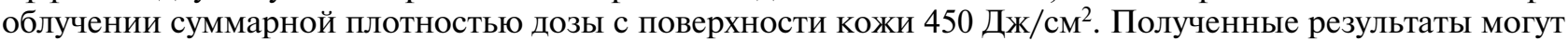
быть использованы для дальнейшей разработки методов лазеротерапии гипотиреоза в эксперименте.

Ключевые слова: VEGF; лазерное излучение; щитовидная железа; гипотиреоз.

Introduction. Laser irradiation of thyroid is successfully used to correct hypothyroidism. The functional state of the organ, the production of thyroid hormones, the vascular bed area, blood flow may change depending on the applied laser exposure. The aim was to study the effect of infrared laser irradiation of average intensity on the expression of vascular endothelial growth factor (VEGF) in thyroid gland tissue.

Material and methods. The experiment was conducted on 30 male rats, divided into 6 groups: 1) intact animals; 2) animal model of hypothyroidism; 3), 4) five-fold $970 \mathrm{~nm}$ laser irradiation of the intact rat thyroid with the total dose density of $112 \mathrm{~J} / \mathrm{cm}^{2}$ and $450 \mathrm{~J} / \mathrm{cm}^{2} ; 5$ ), 6) five-fold $970 \mathrm{~nm}$ laser irradiation of the thyroid of rats with hypothyroidism with the total dose density of $112 \mathrm{~J} / \mathrm{cm}^{2}$ and $450 \mathrm{~J} / \mathrm{cm}^{2}$ Hypothyroidism was modeled with mercazolil at $25 \mathrm{mg} / \mathrm{kg}$ for 21 days [1]. The removal from the experiment was carried out 1 day after. Expression of VEGF was determined immunohisto- chemically using specific antibodies (Biorbyt, USA) and labeling system based on Biotin-streptavidinperoxidase method. The results were analyzed using ImageScope computer program, combined with "DMRXA" microscope ("Leica", Germany).

Results and discussion. The expression of VEGF after hypothyroidism simulation increased. We found the presence of the growth factor in endothelial cells, in basal membrane area, in perivascular and interlobular connective tissue. Laser irradiation of thyroid both in intact control and in animals with hypothyroidism model at the dose of $112 \mathrm{~J} / \mathrm{cm}^{2}$ and $450 \mathrm{~J} / \mathrm{cm}^{2}$ caused the increase of VEGF expression, while the changes were more pronounced in the group of animals with hypothyroidism.

According to the literature, the activation of neoangiogenesis requires an increase in the level of growth factors and their receptors in the localization of the future vessel, which in turn contributes to increased vascular permeability, the interaction of proteolytic enzymes and other growth factors, 
the destruction of contacts between endothelial cells and basal membranes, cell migration [2]. Matrix metalloproteinases and plasma-dependent proteolysis are activated as a result of vascular wall fenestration, so creating preconditions for neoangiogenesis.

We explained the increased expression of VEGF after hypothyroidism modeling by activation of compensatory angiogenic mechanisms, increasing the vascular bed area and blood flow to eliminate the deficit of thyroid hormones. We supposed the increase in VEGF expression a day after laser ir- radiation of thyroid with the total dose density of both $112 \mathrm{~J} / \mathrm{cm}^{2}$ and $450 \mathrm{~J} / \mathrm{cm}^{2}$ in the intact control group and in animals with hypothyroidism model was associated with laser stimulating effect on VEGF producing cells. Changes at high dose were more pronounced (from 4.44 r.u. to 8.89 and 22.22 r.u. in intact animals; from 8.89 r.u. to and 22.22 and 26.67 r.u. in animals with the hypothyroidism model).

Conclusion. The obtained results could be used for further development of laser therapy methods for hypothyroidism in experiment.

\section{References}

1. Isman CA, Yegen BC, Alican I. Methimazole-induced hypothyroidism in rats ameliorates oxidative injury in experimental colitis. J. Endocrinol. 2003;177(3):471-476.

2. Winter R, Dungel P, Reischies F. Photobiomodulation (PBM) promotes angiogenesis in vitro and in chick embryo chorioallantoic membrane model. Sci Rep. 2018;8(1):170-180. 